\title{
VARIATIONS OF SELECTED SOIL PROPERTIES IN THE GRASS FIELDS INVADED AND UNINVADED BY INVASIVE GOLDENROD (Solidago canadensis L.)
}

\author{
BEÁTA BARANOVÁ ${ }^{1}$, DANICA FAZEKAŠOVÁ ${ }^{1,2}$, PETER MANKO ${ }^{1}$
}

\begin{abstract}
${ }^{1}$ Department of Ecology, Faculty of Humanities and Natural Sciences, University of Prešov, 17. novembra 1, 08116 Prešov, Slovak Republic; e-mail: bbaranova@gmail.com, peter.manko@unipo.sk

${ }^{2}$ Department of Environmental Management, Faculty of Management, University of Prešov, Slovenská 67, 08001 Prešov, Slovak Republic; e-mail: danica.fazekasova@unipo.sk
\end{abstract}

\begin{abstract}
Baranová B., Fazekašová D., Manko P.: Variations of selected soil properties in the grass fields invaded and uninvaded by invasive goldenrod (Solidago canadensis L.). Ekológia (Bratislava), Vol. 36, No. 2, p. 101-111, 2017.

Although the invasion of exotic plants has been recognised as the serious cause of the biodiversity loss and natural habitats degradation and threat to the ecosystems functions, just the little attention has been paid to the potential impacts of the goldenrod invasion on the soil properties. Equally, currently obtained results are contrary and ambiguous. We tested whether the grass fields invaded and uninvaded by Canadian goldenrod (Solidago canadensis L.) differ in $\mathrm{pH}$, soil moisture, organic carbon (Cox), humus and $\mathrm{P}, \mathrm{K}$ and $\mathrm{Mg}$ contents and related the variations to the chosen environmental variables. We did not find significant distinctions of the studied types of habitats in the selected physico-chemical soil properties as well as the relation between the goldenrod invasion and the changes in soil properties. Nevertheless, whereas the soil reaction, soil moisture and $\mathrm{Mg}$ content were higher in the invaded soils, the Cox, humus and $\mathrm{P}$ and $\mathrm{K}$ contents were higher in the uninvaded ones. Doubtless, further attention need to be paid to this problem.
\end{abstract}

Key words: Canadian goldenrod, plant invasion, physico-chemical soil properties.

\section{Introduction}

Plant invasion is a significant component of global changes. Economic globalisation and intercontinental transport contribute to the increase in number of new, non-native neophytes. Some of them were able to establish and spread rapidly within countries out of their origin, occupying mostly disturbed, anthropic, slowly renewed or eutrophicated habitats. Pollution, lack of nutrition, water and light, natural plant cover removal, anthropogenic interventions or soil cover disturbances make the native plant cover more susceptible to the invasive neophytes introduction. Over the past two decades, exotic plants invasion has been regognised as the serious cause of the biodiversity loss and natural habitats degradation (Cvachová, Gojdičová, 2003; Jakobs et al., 2004; Chapuis-Lardy et al., 2006; Gális et al., 2016). 
The non-indigenous invasive goldenrod, Solidago canadensis L. (Asteraceae), is the perennial herb native to the North America which got into the middle of Europe as an ornamental, schizanthus and melliferous plant and unintentionally spread from the gardens to the natural environment between the 1850 and 1889. Nowadays, goldenrod is widespread, crowd out the native plant species and generated the characteristic dense and monospecific coenoses. Whilst in the Europe, invasive goldenrod occur in the wide range of soil conditions, in North America, it grows typically on the wet soils (Cvachová, Gojdičová, 2003; Jakobs et al., 2004; Weber, Jakobs, 2005; Koutika et al., 2011; Pauková, 2013). Human impact and changes in vegetation cover are considered to be the important factors affecting the soil formation and development (Penížek, Zádorová, 2012). Owing to the large amount of space that was occupied by the invasive plants and because of the abandonment of invaded habitats, it could be expected that environment changes connected with plant invasion will affect the soil properties. Studies of Kourtev et al. (2003), Chapuis-Lardy et al. (2006), Vanderhoeven et al. (2006), Herr et al. (2007), Zhang et al. (2009) and Scharfy et al. (2009) focus on the pH; organic carbon (Cox); total C, $\mathrm{N}$ and $\mathrm{CaCO}_{3}$ contents; available nitrate and ammonium; soil C:N ratio; available nutrients such as $\mathrm{P}, \mathrm{K}, \mathrm{Mg}, \mathrm{NH}_{4}-\mathrm{N}$ and $\mathrm{NO}_{3} ; \mathrm{P}$ and $\mathrm{N}$ availability; bulk density; water holding capacity; soil moisture; enzymes activity; and soil $\mathrm{CO}_{2}$ release changes in the $S$. canadensis and second of invasive goldenrod, S. gigantea (Aiton), plots. Comparing the invaded plots with uninvaded ones, authors assessed if the goldenrod invasion alters the selected soil properties. Soil reaction and $\mathrm{Ca}, \mathrm{Cu}, \mathrm{Zn}, \mathrm{Mg}, \mathrm{P}, \mathrm{K}, \mathrm{Al}, \mathrm{Mn}$ and $\mathrm{Na}$ contents were studied for the other alien plants too (Kourtev et al., 1998; Scott et al., 2001; Duda et al., 2003; Vanderhoeven et al., 2005; Li et al., 2006; Koutika et al., 2007). In opposite, the impact of selected soil properties on the exotic plants success was also discussed (Hill et al., 2005). It appears that not just the invasion affect the soil properties but that the soil properties on their own could support and contribute to the spread of the non-native neophytes. Summarised data review of the effect of invasive exotic plants on the soil properties was done by Ehrenfeld (2003) and Koutika et al. (2011). However, obtained results are contrary and ambiguous, and the conclusions about the impact of invasion on the soil parameters are still not absolutely clear.

Despite the increasing interest of the scientific community for the impact of exotic neophytes invasion on the ecosystem properties, very few studied concerning the European subcontinent have been published (Ehrenfeld, 2003; Vanderhoeven et al., 2005). To our knowledge, no similar study has been published in the Slovakia.

The aim of our study was (a) to evaluate theselected physico-chemical soil properties of uninvaded grass fields (UIGF) and grass fields invaded by invasive goldenrod (S. canadensis L.), (b) to assess the distinctions of studied types of habitats in the selected soil properties and (c) to correlate the properties to each other and relate them to the chosen environmental variables.

\section{Material and methods}

\section{Study stands and soil samples}

Soil samples were taken in spring 2012 from the depth of 5-15 cm at six UIGF and six Solidago-invaded grass fields (SIGF) (Fig. 1) localised in the urban and suburban zone of Prešov town and surrounding villages, Eastern Slovakia. As the goldenrod invaded stands, grass fields with dominance ( $>80 \%$ mean cover) of invasive goldenrod, 

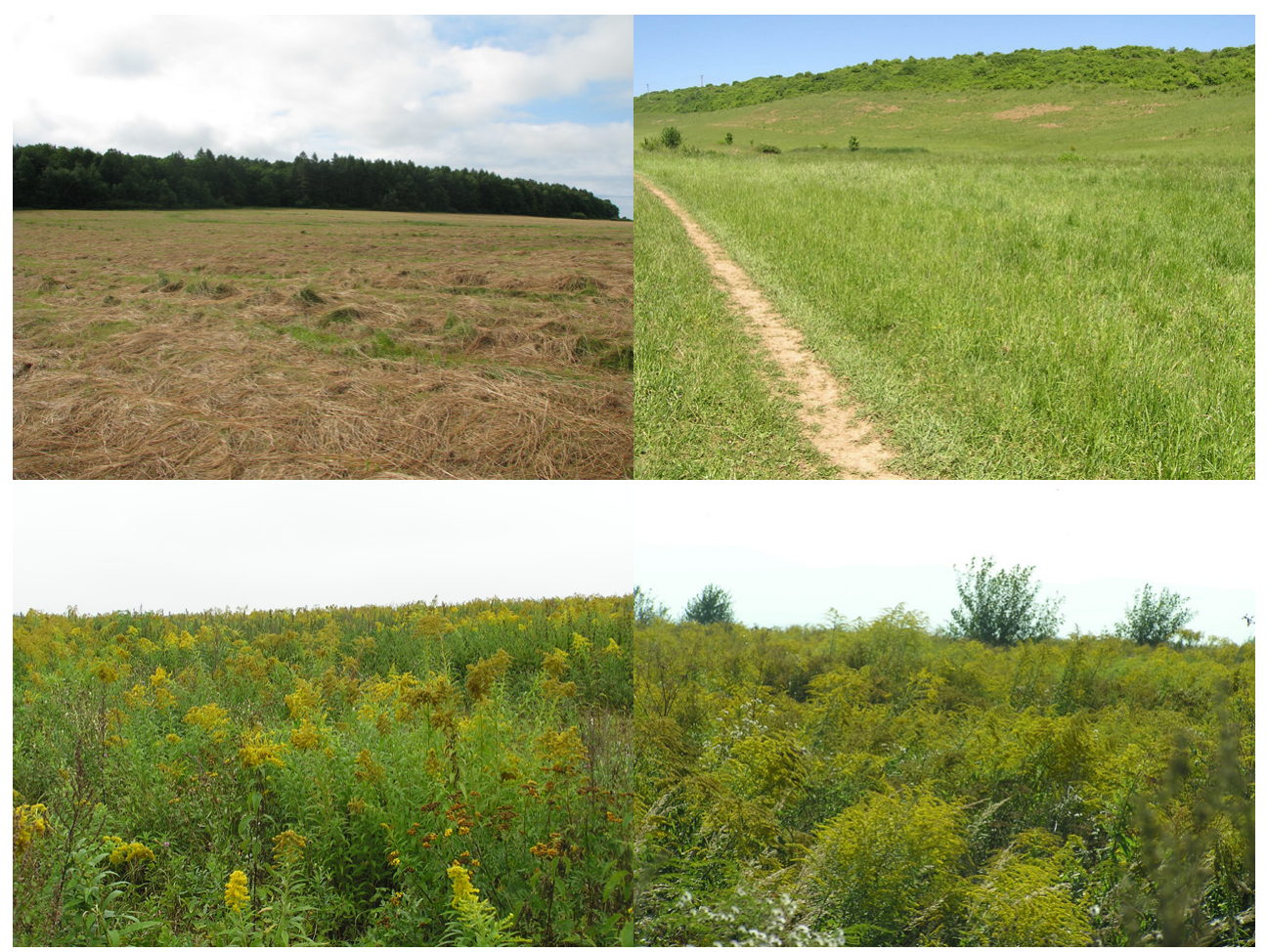

Fig. 1. Uninvaded and Solidago-invaded grass field stands in the urban and suburban zone of Prešov town and surrounding villages, Eastern Slovakia.

S. canadensis L., were studied. The stands varied in the disturbances history. Chosen areas are registered as the grass fields in the national Register of Soil; they used to be managed in the past. Today they represent abandoned habitats without regular agrotechnical interventions. As the comparative biotope, uninvaded, managed (harvested, grazed) grass fields with a dominance of Poaceae family were chosen. Managed grass fields were chosen as the comparative biotope because of the lack of native, non-managed grass fields. Equally, most of the native, non-managed grass fields are just due to ', hands-free' management already partially invaded by invasive neophytes. Every soil sample consisted of 3 sub-samples taken randomly within the stands, but at least in the 25-m spacing to each other. Soil moisture was determined gravimetrically in the fresh soil samples. Consequently, samples were homogenised, large particles were broken down and air dried at room temperature $\left(20-25^{\circ} \mathrm{C} / 7-14\right.$ days). Soil was sieved to $2 \mathrm{~mm}$ and large particles were ground. Samples were stored in the plastic bags until analysis. To measure the $\mathrm{pH}$, a mixture (1:5 ratio) of one part of soil ( $5 \mathrm{~g})$ and five parts of $0.01 \mathrm{M} \mathrm{CaCl}_{2}$ solution $(25 \mathrm{ml})$ were agitated and tested using inoLab pH 720-WTW probe. Cox and available nutrients were determined at the Oddelenie agrochémie a výživy rastlín (AVR) Košice, UKSUP Bratislava. Cox content was measured by the Joblbauer method (Peterburskij, 1963) and converted into humus content using Welte's coefficient (1.724). Contents of available P, K and Mg were evaluated using the Mehlich III (Fiala et al., 1999).

\section{Environmental variables}

Three variables were chosen to represent invasion. Invasive goldenrods are known to cause the decrease in the native-plants species richness, because of the clonal growth, they generated characteristic, dense and monospecific 
coenoses (Cvachová, Gojdičová, 2003; Jakobs et al., 2004). Thus, as the first criterion, the type of vegetation was evaluated as the polyspecific within uninvaded (UIGF) and as the monospecific within Solidago-invaded (SIGF) stands. Canadian goldenrod individuals achieve as adults the mean height of more than $1 \mathrm{~m}$ (Cvachová, Gojdičová, 2003); Poaceae members, which dominate the UIGF, usually do not overlap this height. Thus, as the second criterion, the height of vegetation was take into account, which is evaluated as $<100 \mathrm{~cm}$ within uninvaded (UIGF) and $>100$ $\mathrm{cm}$ within Solidago-invaded (SIGF) stands. Solidago invaders usually occupy abandoned, non-farmed habitats that are, when compared to the uninvaded, managed ones, without the regular agrotechnical interventions such as the harvesting or grazing throughout the most part of the year. 'Hands-free' management, that is, no harvesting regime, is also reflected with the presence of trees and shrubs pioneer vegetation randomly occurring within the chosen goldenrod-invaded stands. The stands remain non-managed just because they are invaded (Cvachová, Gojdičová, 2003; Jakobs et al., 2004). Thus, the measure of agrotechnical interventions was taken into account as the third criterion and evaluated as follows: no interventions per season(p.s.) (0), one intervention p.s. (1), two interventions p.s. (2) and three interventions p.s. (3). Each stand was also characterised by the following soil parameters: soil type, compaction, skeletal and soil grain size according to 'Partial soil monitoring, CMSP database, VÚPOP Bratislava' and BPEJ (Linkeš et al., 1996). Soils were catagorised as pseudogleys (1), regosols (2), cambisols (3), luvisols (4) and fluvisols (5); soil compaction as soil without compaction (0), primary compaction (1), secondary compaction (2) and primary + secondary compaction (3); soil skeletal as soil without skeletal (0), slightly skeletal soils (2), middle skeletal soils (2) and strongly skeletal soils (3); grain size as light soils (1), middle heavy soils (2), heavy soils (3) and very heavy soils (4).

\section{Data analysis}

One-way analysis of variance (ANOVA) was used to test the significance of distinctions between the studied types of habitats in the selected soil properties. The data were log-transformed before statistical analysis. Mean values and standard deviations were evaluated using univariate statistics. The differences between the studied types of habitats in the soil properties were displayed using descriptive statistic. The mutual dependences of the soil and soil properties with the environmental variables were visualised by linear models (ordinary least-squares regression). Analysis were done in PAST 2.17c (Hammer et al., 2001). To assess correlations between the environmental variables and selected soil properties, as well as the soil properties with one other, Spearman correlation coefficient determined in STATISTICA 10 by $\mathrm{p}<0.01$ and $\mathrm{p}<0.05$ was used. Because the length of the longest gradient analysed using differential correlation analysis did not overpass value 3 (Lepš, Šmilauer, 200o), to test and evaluate the effect and significance of environmental variables on the variability of selected soil properties, we used regularised discriminate analysis (linear ordinal method) (Herben, Münzbergová, 2003) with the application of Forward Selection Function in CANOCO software (Ter Braak, Šmilauer, 2002). The data were log-transformed before statistical analysis.

\section{Results and discussion}

The results obtained by the regular soil sampling across the UIGF and grass fields invaded by invasive goldenrods and samples processing, were given in Table 1.

\section{Soil moisture}

In accordance with our exceptions, invaded plots revealed higher mean soil moisture when compared uninvaded ones; however, this distinction was not significant what is in accordance with Scharfy et al. (2009). In association with exotic plants, lower water extraction from the soil because of shallower and smaller root system is expected (Ehrenfeld, 2003). Cultivated grass fields, as mown meadows, are characterised by higher surface temperature and low humidity because of removal of plant cover and thus reducing the shadow (Brom et al., 2009). In opposite, abandoned invaded plots without regular cultivation support the more efficient shadowing and thus reduce the soil heating and evapo-transpiration. The higher 
T a b l e 1. Selected physico-chemical soil properties of the topsoil $(5-15 \mathrm{~cm})$ in UIGF and SIGF stands.

\begin{tabular}{|c|c|c|c|c|c|c|c|c|c|c|c|}
\hline & & & & & & & & Mean & SD & $\min$ & $\max$ \\
\hline \multirow{2}{*}{ W (\%) } & UIGF & 28.2 & 12.3 & 14.1 & 28.6 & 31.0 & 22.0 & 22.70 & 7.96 & 12.3 & 31.0 \\
\hline & SIGF & 25.6 & 17.6 & 23.8 & 19.3 & 29.4 & 31.6 & 24.55 & 5.49 & 17.6 & 31.6 \\
\hline \multirow{2}{*}{$\mathrm{pH}\left(\mathrm{CaCl}_{2}\right)$} & UIGF & 4.6 & 6.2 & 6.9 & 6.6 & 6.8 & 5.0 & 6.02 & 0.98 & 4.6 & 6.9 \\
\hline & SIGF & 5.7 & 6.9 & 7.3 & 5.6 & 4.9 & 6.2 & 6.1 & 0.89 & 4.9 & 7.3 \\
\hline \multirow{2}{*}{$\operatorname{Cox}(\%)$} & UIGF & 4.00 & 1.77 & 1.71 & 2.24 & 2.54 & 1.50 & 2.29 & 0.92 & 1.5 & 4.0 \\
\hline & SIGF & 2.26 & 1.74 & 1.09 & 1.41 & 2.15 & 2.08 & 1.79 & 0.46 & 1.09 & 2.26 \\
\hline \multirow{2}{*}{ Humus (\%) } & UIGF & 6.89 & 3.06 & 2.95 & 3.87 & 4.39 & 2.59 & 3.96 & 1.58 & 2.59 & 6.89 \\
\hline & SIGF & 3.89 & 3.00 & 1.88 & 2.43 & 3.71 & 3.58 & 3.08 & 0.80 & 1.88 & 3.89 \\
\hline \multirow{2}{*}{$P\left[\mathrm{mg} \mathrm{kg}^{-1}\right]$} & UIGF & 20 & 88 & 55 & 459 & 23 & 63 & 118 & 169 & 20 & 459 \\
\hline & SIGF & 173 & 79 & 55 & 37 & 20 & 232 & 99.3 & 84.36 & 20 & 232 \\
\hline \multirow{2}{*}{$\mathrm{K}\left[\mathrm{mg} \mathrm{kg}^{-1}\right]$} & UIGF & 378 & 295 & 247 & 383 & 331 & 168 & 300.3 & 82.69 & 168 & 383 \\
\hline & SIGF & 1038 & 217 & 187 & 265 & 184 & 523 & 402.3 & 336.4 & 184 & 1038 \\
\hline \multirow{2}{*}{$\mathrm{Mg}\left[\mathrm{mg} \mathrm{kg}^{-1}\right]$} & UIGF & 381 & 479 & 349 & 292 & 528 & 155 & 364 & 133.8 & 155 & 528 \\
\hline & SIGF & 296 & 357 & 238 & 355 & 186 & 205 & 272.8 & 74.47 & 186 & 357 \\
\hline
\end{tabular}

Notes: $\mathrm{pH}$ - soil reaction; $\mathrm{W}$ - soil moisture; Cox - organic carbon; $\mathrm{P}$ - phosphorus; $\mathrm{K}$ - potassium; Mg - magnesium.

environment humidity is reflected, for example, in the increasing number of ground beetles (Coleoptera:Carabidae) highly perceptive to soil moisture and decreasing number of xerophilous species within the invaded stands (Kappes et al., 2007; Topp et al., 2008; Hansen et al., 2009).

\section{Soil reaction}

Equally, we did not observe any significant distinction between uninvaded and Solidagoinvaded stands in soil reaction as well as any correlations between soil reactions and any of the other selected soil properties. Our results are in accordance with Duda et al. (2003), Herr et al. (2007) and Scharfy et al. (2009), who also did not observe any significant distinction between invaded and uninvaded plots in the soil reaction. In opposite, Zhang et al. (2009) and Chapuis-Lardy et al. (2006) confirmed distinctions between the invaded and uninvaded plots in the $\mathrm{pH}$ as significant. Our results are also in contrary to the findings of Herr et al. (2007) and Chapuis-Lardy et al. (2006), that is, the soil pH is consistently lower and significantly decrease in the goldenrod-invaded plots, as well as to that of Kourtev et al. (1998), Li et al. (2006) and Zhang et al. (2009) who observed that soil pH significantly increased with the invasion of Solidago spp., whilst $\mathrm{pH}$ between studied types of habitats was pretty balanced in our study.

\section{Organic carbon and humus content}

In contrary to our expectation, neither organic carbon nor humus content were higher across the invaded plots; equally, the distinctions were not confirmed as significant. We observed 

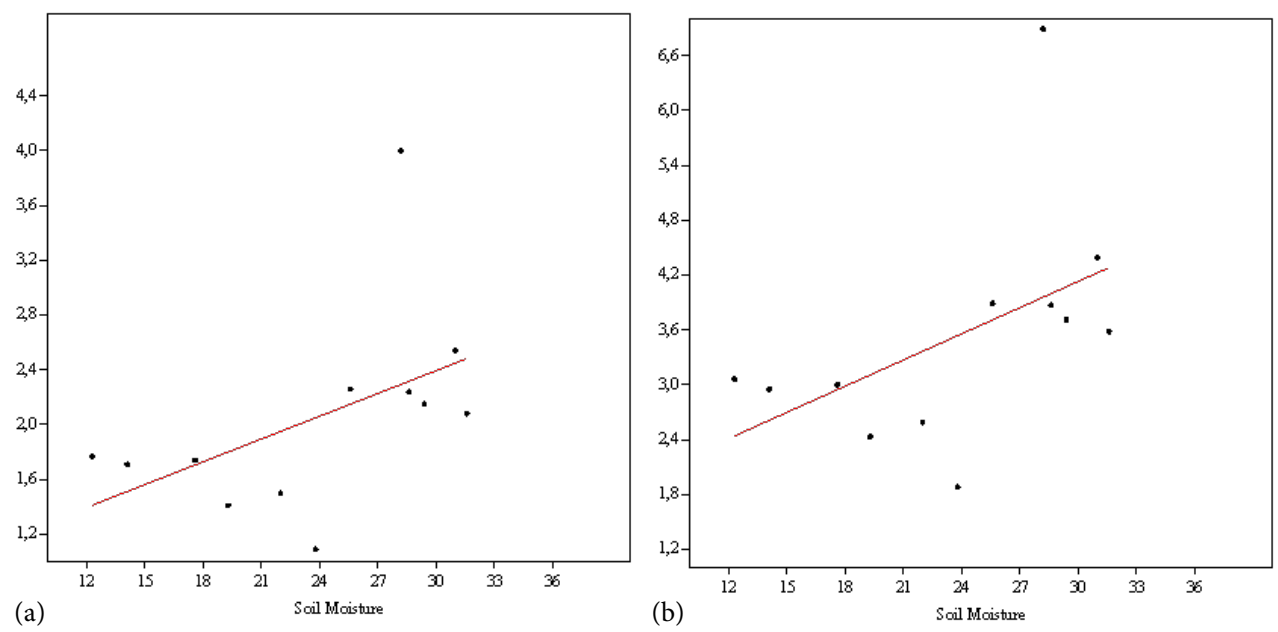

Fig. 2. Linear dependence of (a) the soil moisture and organic carbon content $(\mathrm{p}=0.095)$ and $(\mathrm{b})$ the soil moisture and humus content $(\mathrm{p}=0.095)$.

significant $(\mathrm{p}<0.05)$ positive correlation between Cox and humus content with the soil moisture (Fig. 2), as the carbon dynamics is strongly affected by the soil humidity (Ehrenfeld, 2003). The another of invasive representatives of Solidago genus in the middle Europe S. gigantea has a greater mean concentration of carbon. Because the litter decomposition rates is strongly influenced by the C:N ratio (Herr et al., 2007), goldenrod tissues supposed to decompose slower. Together with the increased biomass production and leaves litter fall, it partially explains the increase in Cox under stands of invasive plants (Scott et al., 2001). Recent studies suggest that the biomass of detritophagous soil fauna groups, which contribute to humification process, increase in invaded habitats. Greater biomass production is one of the effects most frequently associated with the plant invasion; stands not cultivated by man reveal high amount of detritus and organic matter. Then, the groups feeding upon dead and decaying plant organic matter profit from the permanent presence of a huge amount of plant litter. The invaded plots point the higher decomposition rates, food chain change from plant based to detritus based (Ehrenfeld, 2003; Ernst, Cappuccino, 2005; Chapuis-Lardy et al., 2006; Frouz et al., 2007; de Groot et al., 2007; Herr et al., 2007; Topp et al., 2008; Brom et al., 2009). Accordingly, the higher humus content could be expected in the invaded plots. But, in our study, neither Cox nor humus contents were higher in the invaded plots; equally, the distinctions were not confirmed as significant. Our findings are in contrary to Duda et al. (2003), Koutika et al. (2007) and Zhang et al. (2009), that Cox increase significantly in connection with Solidago invasion. According to Scharfy et al. (2009), the total C concentration increase by $6 \%$ in goldenrod-invaded soils. The Cox might be used even as indicator of $S$. canadensis density (Zhang et al., 2009). In opposite, according to Kourtev et al. (2003) and Li et al. (2006), Cox significantly decrease in the invaded sites because of the high nitrogen uptake by exotic plants and their competition with the soil community. 
Although the mean value of phosphorus was higher within uninvaded stands, according to descriptive statistic (Fig. 3), P content was higher in the invaded plots. The highest P content was assigned for the uninvaded stand n.4. Excluding this value, the mean P content of uninvaded soils would be $49.8 \mathrm{mg} \mathrm{kg}^{-1}$. We did not confirm the correlations of phosphorus with any of the other selected soil properties; equally, the distinction between UIGF and SIGF in phosphorus content was not significant. According to Zhang et al. (2009), S. canadensis invasion results in significant decrease of available phosphorus content. Duda et al. (2003), Chapuis-Lardy et al. (2006), Herr et al. (2007) and Scharfy et al. (2009) obtained the contrary findings. S. canadensis as the mycotrophic species efficiently uptake the phosphorus from the soil with the help of arbuscular mycorrhizal fungi (Bagayoko et al., 2000; Jin et al., 2004). Dead goldenrod leaves have higher concentration of phosphorus; then, litter quality can influence the soil P status within invaded soils. $\mathrm{P}$ concentration can also increase due to active acidification or rapid turnover of the fine roots in the winter time (Herr et al., 2007). That is why the $\mathrm{P}$ dynamics is enhanced in the soils invaded by Solidago spp. (Chapuis-Lardy et al., 2006). Scharfy et al. (2009) did not confirm the significant effect of the $S$. gigantea on the phosphate concentration or
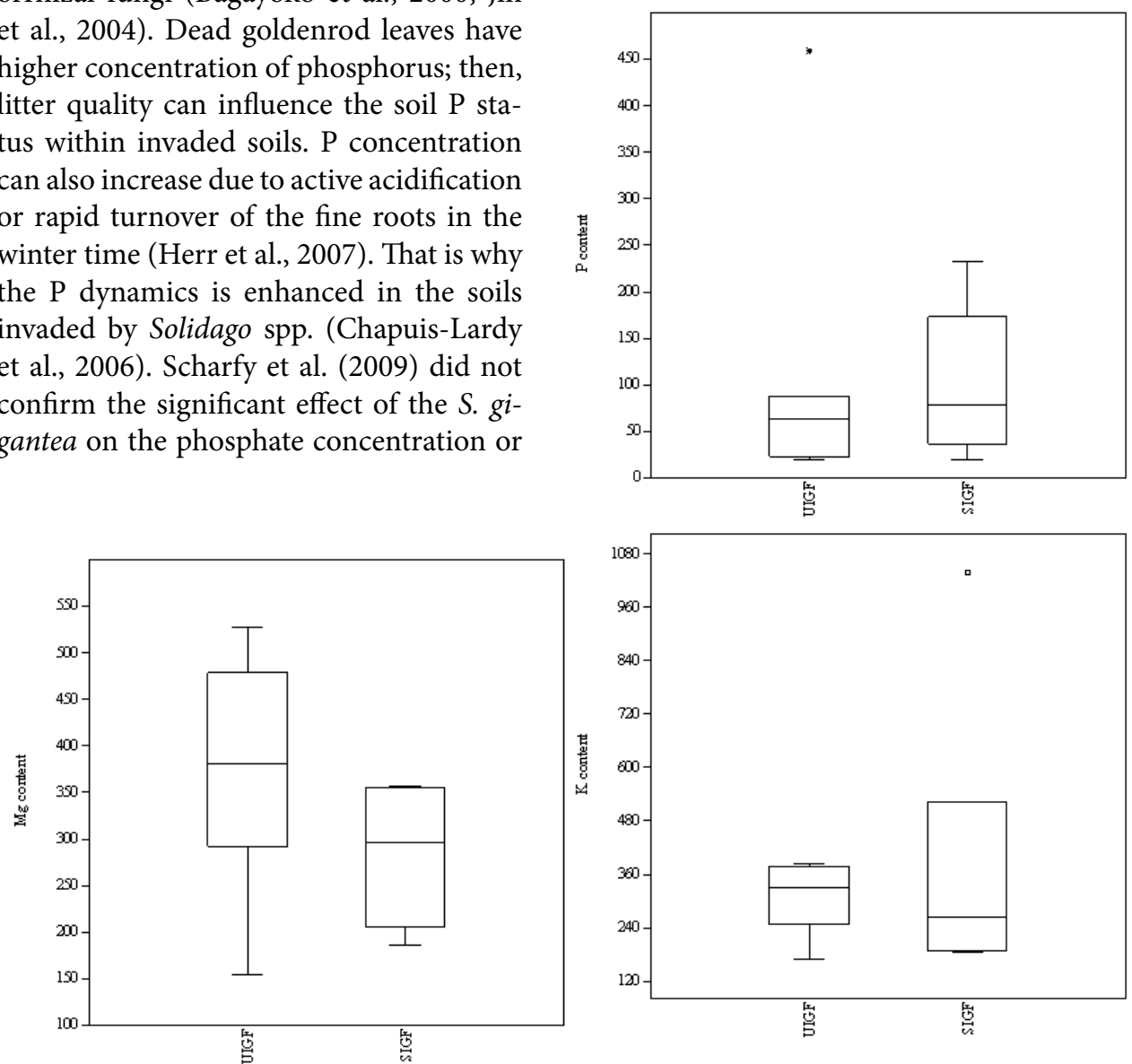

Fig. 3. Contents of the available nutrients in the invaded and uninvaded stands. Notes: UIGF, uninvaded grass fields; SIGF, Solidago-invaded grass fields. 
$\mathrm{P}$ availability. But, the significant interaction between the $\mathrm{P}$ availability and the soil C:N ratio was observed, as the C:N ratio is reduced when the $\mathrm{P}$ availability is lower and vice versa.

We determined higher mean value of potassium content in the invaded stands. But, according to the descriptive statistic (Fig. 3), mean K content was higher in the uninvaded one, whilst, for example, Herr et al. (2007) observed higher K content under the S. gigantea stands. Potassium content assigned for the Solidago-invaded stand n.1 exceeded more than two times the mean value. Excluding this value, the average K content of invaded soils would be $275.2 \mathrm{mg}$ $\mathrm{kg}^{-1}$ and so lower, or pretty balanced with uninvaded plots. K content did not differ significantly between the UIGF and SIGF what is in contrary to Vanderhoeven et al. (2005).

We observed lower mean value of magnesium content in the Solidago-invaded plots when compared to uninvaded ones. Our findings are inconsistent with Herr et al. (2007), who observed that the Solidago-invaded stands revealed higher Mg content, also in contrary to Vanderhoeven et al. (2005), as the distinction between invaded and uninvaded plots in $\mathrm{Mg}$ content was not significant. Magnesium did not correlate with any of the other selected soil properties.

We observed the significant $(\mathrm{p}<0.05)$ and positive correlations between $\mathrm{K}$ and Cox as well as $\mathrm{K}$ and humus contents (Fig. 4).
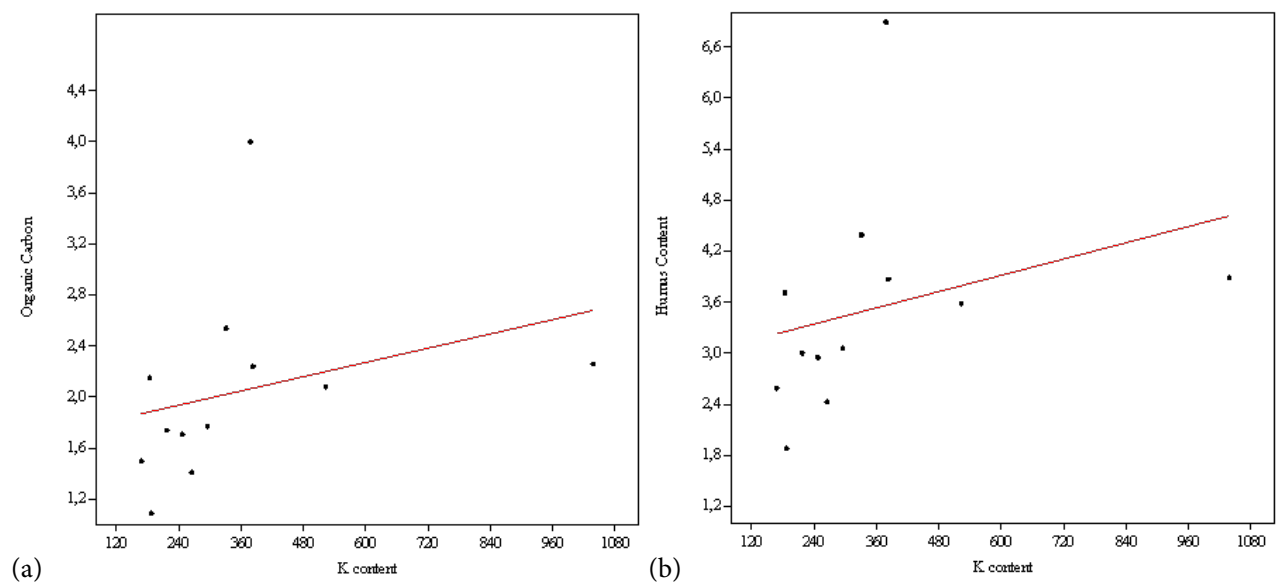

Fig. 4. Linear dependence of (a) the potassium and organic carbon content $(p=0.26)$ and $(b)$ the potassium and humus content $(\mathrm{p}=0.26)$.

\section{Environmental variables}

We observed significant $(\mathrm{p}<0.01)$ positive correlations between soil reaction and soil compaction as well as $\mathrm{pH}$ and soil type $(\mathrm{p}<0.05)$. The relation of selected soil properties to environmental variables is shown in the biplot (Fig. 5). However, our study did not find any effect of any of the environmental variables on the variation of selected soil properties within the 


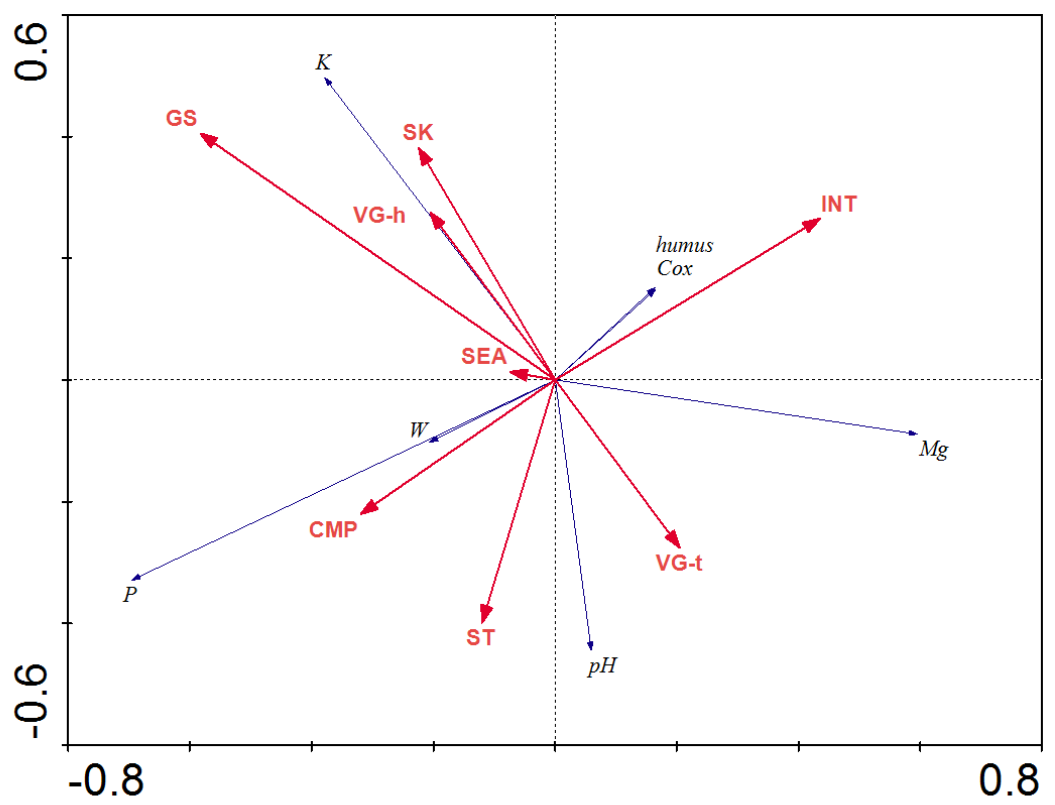

Fig. 5. First two axes of RDA biplot of selected soil properties and eight environmental variables.

Abbreviations and notes: $\mathrm{W}$ - soil moisture; $\mathrm{pH}$ - soil reaction; humus - humus content; Cox - organic carbon content; $\mathrm{P}$ - phosphorus content; $\mathrm{K}$ - potassium content; $\mathrm{Mg}$ - magnesium content; ST - soil type; CMP - compaction; SK - skeletal; GS - grain size; VG-h - vegetation high; VG-t - vegetation type; INT - interventions; SEA - season.

studied types of habitats. Thus, we did not confirm clear, unambiguous significant impact of the $S$. canadensis invasion on the selected physico-chemical soil properties.

\section{Conclusion}

Although we did not confirm the significant impact of the neophyte invader S. canadensis on the selected soil properties, our results do not imply that the goldenrod invasion is unproblematic for nature conservation. Doubtless, the biomass and the litter production of Solidago should be reduced as much as possible, for example, through harvesting (Skórka et al., 2010). Rather, our results highlight the need to pay more attention to study of this problematic, wider spectrum of invaded habitats should be considered (Herr et al., 2007). Quantitative evaluation of the ecological impact of plant invasion is necessary in order to optimise the management of invaded habitats (Ernst, Cappuccino, 2005; Gerber et al., 2008).

\section{Acknowledgements}

The research was supported by the University of Prešov grant agency for $\mathrm{PhD}$ students and young researchers, VEGA 1/0627/12 and KEGA 012PU-4/2012. 


\section{References}

Bagayoko, M., George, E., Römheld, V. \& Buerkert A. (2000). Effects of mycorrhizae and phosphorus on growth and nutrient uptake of millet, cowpea and sorghum on a West African soil. J. Agric. Sci., 135, 399-407.

Brom, J., Procházka, J. \& Rejšková A. (2009) Evaluation of functional properties of various types of vegetation cover using remotely sensed data analysis. Soil and Water Research, 4, S49-S58.

Cvachová, A. \& Gojdičová E. (2003). Regulation for the invasive plant species removal (in Slovak). Banská Bystrica: ŠOP SR.

de Groot, M., Kleijn, D. \& Jogan N. (2007). Species groups occupying different trophic levels respond differently to the invasion of semi-natural vegetation by Solidago canadensis. Biol. Conserv., 136, 612-617. DOI: 10.1016/j. biocon.2007.01.005.

Duda, J.J., Freeman, D.C., Emlen, J.M., Belnap, J., Kitchen, S.G., Zak, J.C., Sobek, E., Tracy, M. \& Montane J. (2003). Differences in native soil ecology associated with invasion of the exotic annual chenopod, Halogeton glomeratus. Biol. Fertil. Soils, 38, 72-77. DOI: 10.1007/s00374-003-0638-x.

Ehrenfeld, J.G. (2003). Effects of exotic plant invasions on soil nutrient cycling processes. Ecosystems, 6, 503-523. DOI: $10.1007 / \mathrm{s} 10021-002-0151-3$.

Ernst, C.M. \& Cappuccino N. (2005). The effect of an invasive alien vine, Vincetoxicum rossicum (Asclepiadaceae) on arthropod populations in Ontario old fields. Biol. Invasions, 7, 417-425. DOI: 10.1007/s10530-004-4062-4.

Fiala, K., Kobza, J., Matúšková, L., Brečková, V., Makovníková, J., Barančíková, G., Litavec, T., Houšková, B., Chomaničová, A. \& Váradiová D. (1999). Partial monitoring system - soil: mandatory statutes (in Slovak). Bratislava: VÚPOP.

Frouz, J., Elhottová, D., Pižl, V., Tajovský, K., Šourková, M., Picek, T. \& Malý S. (2007). The effect of litter quality and soil faunal composition on organic matter dynamics post-mining soil: A laboratory study. Appl. Soil Ecol., 37, 72-80. DOI: 10.1016/j.apsoil.2007.04.001

Gális, M., Galková, J. \& Straňák J. (2016). Impact of secondary landscape structure on the presence of non-native plant species in the cadastral area of the Topolčany town. Ekológia (Bratislava), 35, 136-147. DOI: 10.1515/eko-2016-0011.

Gerber, E., Krebs, Ch., Murrell, C., Moretti, M., Rocklin, R. \& Schaffner U. (2008). Exotic invasive knotweeds (Fallopia spp.) negatively affect native plant and invertebrate assemblages in European riparian habitats. Biol. Conserv., 141, 646-654. DOI: 10.1016/j.biocon.2007.12.009.

Hammer, O., Harper, D.A.T. \& Ryan P.D. (2001). PAST: Palaeontological statistics software package for education and data analysis. Palaeontologia Electronica, 4, 9.

Hansen, A.K., Ortega, Y.K. \& Six D.L. (2009). Comparison of Ground Beetle (Coleoptera: Carabidae) Assemblages in Rocky Mountain Savannas Invaded and Un-Invaded by an Exotic Forb, Spotted Knapweed. Northwest Sci., 83(4), 348-360. DOI: 10.3955/046.083.0406.

Herben, T. \& Münzbergová Z. (2003). Geobotanical data processing in examples. Part I. Data of species composition (in Czech). Praha: PřF UK.

Herr, C., Chapuis-Lardy, L., Dassonville, N., Vanderhoeven, S. \& Meerts P. (2007). Seasonal effect of the exotic invasive plant Solidago gigantea on soil pH and P fractions. J. Plant Nutri. Soil Sci., 170, 729-738. DOI: 10.1002/ jpln.200625190.

Hill, S.J., Tung, P.J. \& Leishman M.R. (2005). Relationships between anthropogenic disturbance, soil properties and plant invasion in endangered Cumberland Plain Woodland, Australia. Austral Ecol., 30, 775-788. DOI: 10.1111/j.1442-9993.2005.01518.x.

Chapuis-Lardy, L., Vanderhoeven, S., Dassonville, N., Koutika, L.-S. \& Meerts P. (2006). Effect of the exotic invasive plant Solidago gigantea on soil phosphorus status. Biol. Fertil. Soils, 42, 481-489. DOI: 10.1007/s00374-0050039-4.

Jakobs, G., Weber, E. \& Edwards P.J. (2004). Introduced plants of the invasive Solidago gigantea (Asteraceae) are larger and grow denser than conspecifics in the native range. Divers. Distrib., 10, 11-19. DOI: 10.1111/j.14724642.2004.00052.x.

Jin, L., Gu, Y., Xiao, M., Chen, J. \& Li B. (2004). The history of Solidago canadensis invasion and the development of its mycorrhizal associations in newly-reclaimed land. Funct. Plant Biol., 31, 979-986. DOI: 10.1071/FP04061.

Kappes, H., Lay, R. \& Topp W. (2007). Changes in different trophic levels of litter-dwelling macrofauna associated with giant knotweed invasion. Ecosystems, 10, 734-744. DOI: 10.1007/s10021-007-9052-9.

Kourtev, P.S., Ehrenfeld, J.G. \& Häggblom M. (2003). Experimental analysis of the effect of exotic and native plant 
species on the structure and function of soil microbial communities. Soil Biol. Biochem., 35, 895-905. DOI: 10.1016/S0038-0717(03)00120-2

Kourtev, P.S., Ehrenfeld, J.G. \& Huang W.Z. (1998). Effects of exotic plant species on soil properties in hardwood forests of New Jersey. In R.K. Wieder, M. Novák \& J. Černý (Eds.), Biogeochemical investigations at watershed, landscape and regional scales (pp. 493-501). Netherlands: Springer. DOI: 10.1007/978-94-017-0906-4_45.

Koutika, L.-S., Vanderhoeven, S., Chapuis-Lardy, L., Dassonville, N. \& Meerts P. (2007). Assessment of changes in soil organic matter following invasion by exotic plant species. Biol. Fertil. Soils, 44, 331-341. DOI: 10.1007/ s00374-007-0210-1.

Koutika, L-S., Rainey, H.J. \& Dassonville N. (2011). Impacts of Solidago gigantea, Prunus serotina, Heracleum mantegazzianum and Fallopia japonica invasions on ecosystems. Applied Ecology and Environmental Research, 9(1), 73-83. http://www.ecology.uni-corvinus.hu

Lepš, J. \& Šmilauer P. (2000). Multidimensional ecological data analysis (in Czech). České Budějovice: BF Jihočeské Univerzity.

Li, W., Zhang, C., Jiang, H., Xin, G. \& Yang Z. (2006). Changes in soil microbial community associated with invasion of the exotic weed, Mikania micrantha H.B.K. Plant Soil, 281, 309-324. DOI: 10.1007/s11104-005-9641-3.

Linkeš, V., Pestún, V. \& Džatko M. (1996). Guide for the BPEJ maps using (in Slovak). Bratislava.

Pauková, Ž. (2013). Invasive plant speciec in the three microregions of Nitra region, south-west Slovakia. Ekológia (Bratislava), 32, 262-266. DOI: 10.2478/eko-2013-0022.

Penížek, V., \& Zádorová T. (2012). Soil topsequence under man-planted vegetation in the Krkonoše Mts., Czech Republic. Soil and Water Research, 7, 138-150.

Peterburskij, A.V. (1963). Praktikum po agronomičeskoj chimii. Moskva: Izd. Selskochozjejstvennoj literatury, žurnalov a plakatov.

Scott, N.A., Saggar, S. \& McIntosh P.D. (2001). Biogeochemical impacts of Hieracium invasion in New Zealand's grayed tussock grasslands: Sustainability implications. Ecol. Appl., 11, 1311-1322. DOI: 10.1890/1051-0761(2001)011[1311:BIOHII]2.0.CO;2

Scharfy, D., Eggenschwiler, H., Venterink, H.O., Edwards, P.J. \& Güsewell S. (2009). The invasive alien plant species Solidago gigantea alters ecosystem properties across habitats with differing fertility. J. Veg. Sci., 20, 1072-1085. DOI: 10.1111/j.1654-1103.2009.01105.x.

Skórka, P., Lenda, M. \& Tryjanowski P. (2010). Invasive alien goldenrods negatively affect grassland bird communities in Eastern Europe. Biol. Conserv., 143, 856-861. DOI: 10.1016/j.biocon.2009.12.030

Ter Braak, C.J.F. \& Šmilauer P. (2002). CANOCO Reference manual and CanoDraw for Windows User's guide. Sftw. For Canonical Community Ordination (version 4.5). New York: Microcomputer Power.

Topp, W., Kappes, H. \& Rogers F. (2008). Response of ground - dwelling beetle (Coleoptera) assemblages to giant knotweed (Reynoutria spp.) invasion. Biol. Invasions, 10, 381-390. DOI: 10.1007/s10530-007-9137-6.

Vanderhoeven, S., Dassonville, N. \& Meerts P. (2005). Increased topsoil mineral nutrient concentrations under exotic invasive plants in Belgium. Plant Soil, 275, 169-179. DOI: 10.1007/s11104-005-1257-0.

Vanderhoeven, S., Dassonville, N., Chapuis-Lardy, L., Hayez, M. \& Meerts P. (2006). Impact of the invasive alien plant Solidago gigantea on primary productivity, plant nutrient content and soil mineral nutrient concentrations. Plant Soil, 286, 259-268. DOI: 10.1007/s11104-006-9042-2.

Weber, E. \& Jakobs G. (2005). Biological flora of central Europe: Solidago gigantea Aiton. Flora - Morphology, Distribution, Functional Ecology of Plants, 200, 109-118. DOI: 10.1016/j.flora.2004.09.001.

Zhang, Ch.B., Wang, J., Qiana, B.Y. \& Li W.H. (2009). Effects of the invader Solidago canadensis on soil properties. Appl. Soil Ecol., 43, 163-169. DOI: 10.1016/j.apsoil.2009.07.001. 